\title{
Physico-chemical study of groundwater in the Northeast of Kara region (Togo)
}

\author{
S. ZOULGAMI ${ }^{1}$, M. D. T. GNAZOU ${ }^{1,2^{*}}$, T. KODOM ${ }^{1}$, \\ G. DJANEYE-BOUNDJOU ${ }^{1}$ and L. M. BAWA ${ }^{1}$ \\ ${ }^{1}$ Laboratory of Water Chemistry, Faculty of Science, University of Lomé, PO. Box: 1515 - Lomé, Togo. \\ ${ }^{2}$ Department of Geology, Faculty of Science, University of Lomé, PO. Box: 1515 - Lomé, Togo. \\ *Corresponding author; E-mail: mgnazou@yahoo.fr
}

\begin{abstract}
Groundwater is a major source of drinking water for people in the Kara region. This study aims at improving the knowledge of groundwater and to determine the processes responsible for groundwater mineralization in this region using hydro-chemical methods and multivariate statistical analysis. 47 water samples taken from the wells in the crystalline basement aquifer were analyzed. Chemical analyses were made on these samples according AFNOR methods to determine hydro-chemical characteristics. The hydro-chemical study showed that the waters in the region have an average temperature of $28.7^{\circ} \mathrm{C}$. They are acid to slightly basic, with a $\mathrm{pH}$ ranging between 5.7 and 7.87, but for the most part neutral. The waters are weakly to moderately mineralized, which confirms the well-known chemical characteristic of basement groundwater. However, high conductivity values were found in the waters in some localities. The highest value was measured at Broukou $\left(1083 \mu \mathrm{S} . \mathrm{cm}^{-1}\right)$. Groundwaters in this region belong to a variety of hydro-chemical facies in relation to the type of geological reservoir. Four hydro-chemical facies were identified. The most dominant is the calcic and magnesian bicarbonated facies $(85 \%)$ followed by the sodic-potassic bicarbonated facies (8.5\%). The sodic-potassic chlorinated facies $(2.1 \%)$, calcic and chloride $(2.1 \%)$ and calcic-magnesian sulfated facies are poorly represented in these waters. Major ions which are the cause of the waters mineralization come from rock weathering, hydrolysis of silicated minerals such as anorthite in plagioclase and the decomposition of ferromagnesian minerals such as biotite and amphibole. The contribution of soil leaching and pollution due to anthropic activities is not negligible.
\end{abstract}

(c) 2015 International Formulae Group. All rights reserved.

Keywords: Groundwater, Kara region, hydrochemistry, weathering, hydrolysis, basement complex.

\section{INTRODUCTION}

In Togo, access to drinking water is one of the major preoccupations of the State. Thus, for many decades, the country was equipped with adequate water infrastructure to guarantee drinking water supply to the population. In the North-Eastern region of
Kara, except the Keran prefecture, urban areas are mainly supplied by "Togolaise des Eaux, TdE". Water is captured from the Kozah dam, which produces annually about $2000000 \mathrm{~m}^{3}$ of water (TDE-SDP, 2010). In contrast, in the rural areas, except the villages located near the dam, people use groundwater from 
traditional wells and boreholes equipped with hydraulic hand pumps for drinking purposes. However, due to a significant population growth and aging of the water infrastructure, the water needs of the population are increasing and the work done so far has become insufficient, leading to water shortages in the region. In this region, there are discontinuous aquifers, leading to water shortage in the basement areas because groundwater production is very small. Indeed, water flow rates measured during drilling are low and vary between $0.5 \mathrm{~m}^{3} / \mathrm{h}$ to $10 \mathrm{~m}^{3} / \mathrm{h}$ (DGEA, 2009).

As the supply of drinking water comes mainly from discontinuous aquifers in this region, it is necessary to know the chemical and physical characteristics of these aquifers which are thus far poorly known. This characterization allows one to ensure the conservation and the durability of this resource. Thus, the objective of the present study was to investigate the origin of the different processes that control groundwater mineralization in this basement region.

\section{MATERIALS AND METHODS Study area}

The Kara region extends from latitudes $9^{\circ} 25$ to $10^{\circ} 10^{\prime} \mathrm{N}$ and longitudes $0^{\circ} 15$ to $1^{\circ} 30^{\prime} \mathrm{E}$. The surface area of about $11629 \mathrm{~km}^{2}$ represents $20.5 \%$ of the total area of the country (Addra, 1984). The study area is located in the northeast part and includes four prefectures: Keran, Doufelgou, Binah and Kozah. The population according to the 2010 census is estimated at 468,017 inhabitants (DGSCN, 2011) with a growth rate of $2.8 \%$.

The climate is humid tropical with two seasons, dry and rainy. The average annual rainfall is relatively high and ranges from $1000 \mathrm{~mm}$ to over $1300 \mathrm{~mm}$ in the East and South of the target region. The rainy season usually begins in April with the arrival of the southwest monsoon (high relative humidity), the maximum rainfall is reached by AugustSeptember. The dry season from November to March (Figure 1), characterized by low relative humidity while sunshine and evaporation reach high values. The dry season is also characterized by the harmattan which is a dry wind often accompanied by a haze that limits visibility. Temperatures measured at synoptic station of Kara vary from $25.5^{\circ} \mathrm{C}$ in August to $30.7{ }^{\circ} \mathrm{C}$ in March with an average of $27.4{ }^{\circ} \mathrm{C}$.

The river system is dendritic and belongs to the Volta Basin (Figure 2). There are two sub-basins: the Koumangou-Keran sub-basin in the north and the Kara sub-basin with its tributaries in the south (Figure 2). The drainage system is tropical type with a season characterized by high water levels in rivers from August to September and a low water level season from December to June. The Koumangou and Keran are perennial rivers, with average water flow rates which do not exceed $20 \mathrm{~m}^{3} / \mathrm{s}$ while the Kara has a similar average flow but its water is sometimes very low with an almost total cessation of flow. Geologically, the region (Figure 3) is made from West to East of a stable geological zone and mobile zone. Mobile zone is subdivided into two units namely the external and internal units of the of Dahomeyides chain. The stable area is represented in the northwest of the study area by the Volta Basin which includes the Mango shales. The external units also include a transition zone (Ex Buem), the hill zone and Atacora. The Buem is characterized by shale, quartz-sandstone, hematite, jasper and ferruginous quartzites. The hilly area is marked by a variety of petrographic facies that include the Kante Shale, jasper, metavolcanic rocks and serpentinites. The Atacora is characterized by micaschists, gneisses and quartzites. The internal units are mainly formed by the Kabyè-Sotouboua-Agou complex which is a series of amphibolitic orthogneisses. These crystalline rocks have been affected by intense weathering due to a warm and wet climate. For this reason, a surface regolith of indurated laterite has been formed. Structurally, two phases of deformation affected the basement during the Pan-African orogeny (Taïrou, 2006). 
Hydrogeologically, geological formations in this locality have no interstitial porosity and contain discontinuous aquifers located in the regolith or in fractured rock (Assouma, 1988). These two aquifer formations are hydraulically interconnected and constitute a single aquifer system. In aquifers with fracture porosity, water circulates and is stored in the fissures. The fracture frequency is dependent on the nature of the rocks, their structural position, their bedding and the intensity of tectonic history. The hardest rocks are generally more fractured while schistose rocks, the most deformable, are less fractured. Water storage function in fractured rocks is low because of low practical porosity. In these fractures, water is generally confined under the regolith cover. In regolith aquifers, rock weathering develops along fissures and toward the surface. The weathering products are unequally distributed and form porous mediums concealing aquifers with limited volume. These aquifers are the most exploited by large diameter wells. Hydraulic conductivity of the regolith is generally low and is in the order of 1 to $9.10^{-7} \mathrm{~m} / \mathrm{s}$. The porosity lies between 2 and $5 \%$ and depends on the nature of the bedrock. The average weathering thickness varies from 3 to $15 \mathrm{~m}$. The micaceous metamorphic rock regoliths are usually argillaceous, and so, less productive, while granites and gneisses whose weathering produces coarse quartz sands are more productive (Gilli et al., 2004).

\section{Experimental approach}

This study is based on 47 water samples taken from the drill holes in the crystalline basement aquifer in the northeastern Kara region. Figure 3 showed the geographical location of sample sites. Chemical analyses were made on these samples to determine chemical characteristics of the water. Physical parameters such as temperature, $\mathrm{pH}$, and electrical conductivity were measured in situ using WTW (Wissenschaftliche Technische Werkstätten) type instruments. Water samples for chemical analysis were collected in polyethylene bottles and transported to the Laboratory of Water Chemistry of the University of Lomé for analysis. The physicochemical parameters selected for this study were measured according to AFNOR standards (AFNOR, 1996) summarized in Table 1.

In the field, the coordinates of different boreholes location were taken using a Garmin GPS. All data collected on groundwater in the region have been subjected to hydro-chemical and statistical analysis. From the hydrochemical point of view, the method of chemical classification of water, based on a graphical representation of the data was used. The Piper diagram was used to identify different hydro-chemical facies (Simler, 2005). The multivariate statistical approach was carried out using principal component analysis (PCA) on reduced centered variables and hierarchical ascending classification. Principal component analysis is a mathematical technique that reduces a complex system of correlations to a smaller number of dimensions. The large number of analyses and parameters considered led us use this multidimensional analysis. PCA simultaneously takes into account all the variables and their relationships, and allows us to emphasize phenomena that are not always visible by standard graphics or simple correlations techniques (Lefebvre, 1980, Blavoux et al., 1992). Hierarchical ascending classification is a tool for analyzing hydrochemical data and permits the geochemical model formulation (Yidana et al., 2008). Multivariate statistical analysis was performed using the Xlsat program (Famhy, 2011) on 42 samples and 14 variables. The parameters considered in this analysis are: electrical conductivity, $\mathrm{pH}$, major cations such as $\mathrm{Ca}^{2+}$, $\mathrm{K}^{+}, \mathrm{Na}^{+}, \mathrm{Mg}^{2+}$, major anions including $\mathrm{Cl}^{-}$, $\mathrm{HCO}_{3}{ }^{-}, \mathrm{SO}_{4}{ }^{2-}$ and nutriments $\left(\mathrm{NO}_{3}{ }^{-}\right.$and $\mathrm{NO}_{2}{ }^{-}$, $\mathrm{NH}_{4}{ }^{+}$). The use of these methods will lead to the determination of various processes that govern the mineralization of the groundwater. 


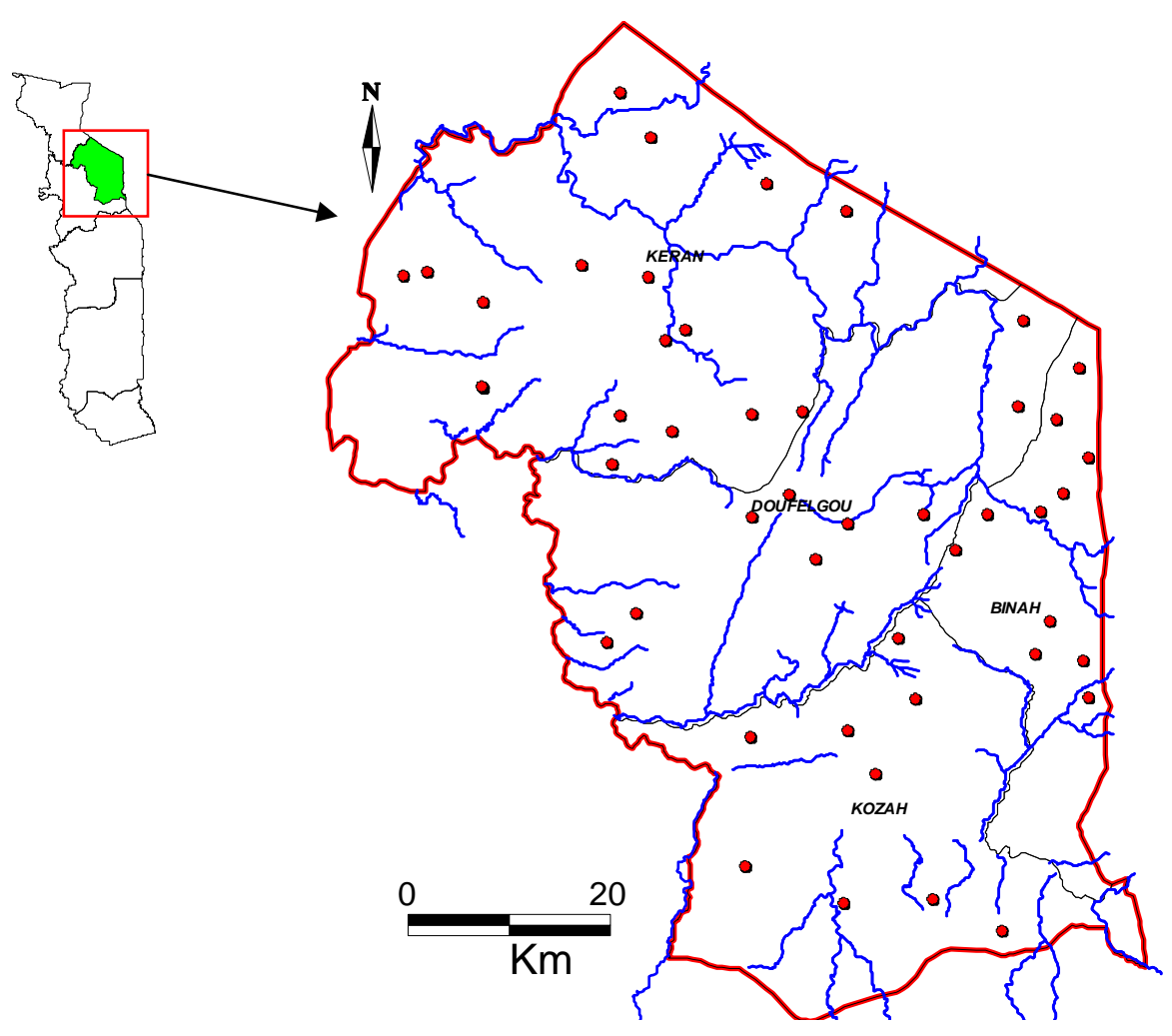

Figure 1: Hydrography of the study area and location of sample sites.

\section{RESULTS}

Physico-chemical results of the groundwater sampled in the Kara region are shown in Table 2. The analysis results were subjected to statistical analysis. Groundwater temperatures vary between $26.1^{\circ} \mathrm{C}$ and $32^{\circ} \mathrm{C}$, with an average of $28.7^{\circ} \mathrm{C}$. The temperature values are akin to that of ambient temperature $\left(27.4{ }^{\circ} \mathrm{C}\right)$. The $\mathrm{pH}$ of water varies between 5.39 and 7.87 with an average of 7.04. More than $75 \%$ of the samples have $\mathrm{pH}$ near neutral. Truly acid samples $(\mathrm{pH}<6.5)$ were detected in shale, quartzite and orthogneiss. These waters are often characterized by low conductivity and correspond to water sampled at Tamde, Teroda, Tawa, Misseouta, Houloulita. The high value of the standard deviation observed in the values of electrical conductivity (245.7) showed significant variations in mineralization of basement aquifers consisting of several geological formations. Indeed, the electrical conductivity of groundwater in the region ranges between 42 and $1083 \mu{\mathrm{S} . \mathrm{cm}^{-1}}^{-1}$, with an average value of $416.7 \mu \mathrm{S} . \mathrm{cm}^{-1}$. Water with high conductivity are those at Broukou (1083 $\left.\mu \mathrm{S} . \mathrm{cm}^{-1}\right)$, Sondè (919 $\left.\mu \mathrm{S} . \mathrm{cm}^{-1}\right)$, Tchitchira $\left(873 \mu \mathrm{S} . \mathrm{cm}^{-1}\right)$, Pangouda $\left(847 \mu{\mathrm{S} . \mathrm{cm}^{-1}}^{-1}\right.$, Chou $\left(801 \mu \mathrm{S} . \mathrm{cm}^{-1}\right)$, Manta $\left(791 \mu\right.$ S.cm $\left.{ }^{-1}\right)$, Kokou-Tamberma (783 $\mu \mathrm{S} . \mathrm{cm}^{-1}$ ) localities. Electrical conductivity variation showed that the waters analyzed are characterized by very low to very high mineralization. To understand the phenomenon of mineralization, we mapped the spatial distribution of conductivity on the geological background of the region (Figure 4). Conductivity distribution showed that the same geological formation presents a variety of conductivities. Highest conductivities are found in the northwest of the study area where the geology is characterized by sandstone and quartz sandstone of the Volta Basin. The 
hardness of the groundwater in the region varies between $1{ }^{\circ} \mathrm{F}$ and $34{ }^{\circ} \mathrm{F}$, with an average of $14.7{ }^{\circ} \mathrm{F}$. The hardness values obtained permit to classify the waters of the region in the range of freshwater to hard water. Hard waters (hardness of about 33 to $34{ }^{\circ} \mathrm{F}$ ) represent only $4 \%$ of the samples and are sampled at Tchéou and Kokou-Temberma.

The waters of the region are characterized by a predominance of bicarbonate ions over chloride ions and sulfates which are practically absent in these waters. However, a high content of sulfate is reported from drilling at Tchéou with concentrations ranging up to $242 \mathrm{mg} / \mathrm{L}$. High concentrations of chloride are also locally reported at Tchitchira (136 mg. $\left.\mathrm{L}^{-1}\right)$, Pangouda (144 mg. $\left.\mathrm{L}^{-1}\right)$ and Sondè (190 mg. $\left.\mathrm{L}^{-1}\right)$. Calcium and magnesium are the most important cations, followed by $\mathrm{Na}^{+}$and $\mathrm{K}^{+}$. All the physico-chemical results showed that waters in the North-Est of Kara region are chemically heterogeneous.

The results of Principal Component Analysis are presented in Tables 2 and 3. Table 2 showed that bicarbonate $\left(\mathrm{HCO}_{3}{ }^{-}\right)$, sodium $\left(\mathrm{Na}^{+}\right)$and calcium $\left(\mathrm{Ca}^{2+}\right)$, with respective averages of $239.7 \mathrm{mg} . \mathrm{L}^{-1}, 32.5$ mg. $\mathrm{L}^{-1} ; 17.3 \mathrm{mg} . \mathrm{L}^{-1}$ and $29.8 \mathrm{mg} . \mathrm{L}^{-1}$ constitute the fundamental parameters which controlled the total mineralization of groundwater in the region.

Significant relationships between the different parameters are given by the correlation matrix (Table 3 ). Indeed, there is a significant correlation between conductivity and the following ions: $\mathrm{HCO}_{3}{ }^{-}(\mathrm{r}=0.80), \mathrm{Ca}^{2+}$ $(\mathrm{r}=0.60), \mathrm{Mg}^{2+}(\mathrm{r}=0.68), \mathrm{Na}^{+}(\mathrm{r}=0.82), \mathrm{Cl}^{-}$ $(\mathrm{r}=0.51), \mathrm{NO}_{3}^{-}(\mathrm{r}=0.62)$. A good correlation also exists between $\mathrm{HCO}_{3}{ }^{-}$ions and $\mathrm{Ca}^{2+}(\mathrm{r}=$ $0.50), \mathrm{Mg}^{2+}(\mathrm{r}=0.60)$ and $\mathrm{Na}^{+}(\mathrm{r}=0.71)$. To a lesser extent, bicarbonates $\left(\mathrm{HCO}_{3}{ }^{-}\right)$are correlated with $\mathrm{pH}(\mathrm{r}=0.43)$. A correlation exists between the nitrogen elements which come from surface pollution and chlorides. Thus, chlorides are well correlated with nitrates $(\mathrm{r}=0.81)$ and ammonium ion $(\mathrm{r}=$ 0.58), which are markers of a surface contribution. Similar behavior can be reported between $\mathrm{Na}^{+}$and chloride ions. As nitrogen elements, a portion of the chloride ions comes from meteoric water, followed by strong evaporation.

The percentage of variability (Figure 5) represented by the first two factors of the PCA (F1 and F2) is not sufficiently high (49.66\%). To avoid misinterpretation of the graphics, we posted F1 and F3 axes which express $45.06 \%$. The most important factor $\mathrm{F} 1,(33.37 \%)$ is determined by electrical conductivity, $\mathrm{HCO}_{3}{ }^{-}$, $\mathrm{Ca}^{2+}, \mathrm{Mg}^{2+}, \mathrm{Na}^{+}$, and $\mathrm{Cl}^{-}$. The elements that define this factor, except nitrate and bicarbonates ions, are the result of a long duration of dissolving after contact between water and rock. These elements characterize the mineralization of water in its reservoir. The strong correlation between these variables and their proximity in the circles showed that the dissolution of these ions is controlled by hydrolysis. Indeed, hydrolysis is a slow process. This phenomenon allows saying that factor F1 gives information about chemical conditions acquired by water. The F1 factor therefore expresses the phenomenon of mineralization-residence time. The rallying together of majority of variables around conductivity showed the influence of weathering-hydrolysis in the ions dissolution. Factor 3 (F3) (11.10\%) is determined by iron and manganese.

Correlation circles as the correlation matrix showed links between chlorides and nitrogen elements particularly $\mathrm{NO}_{3}{ }^{-}(\mathrm{r}=0.81)$ and $\mathrm{NH}_{4}{ }^{+}(\mathrm{r}=0.58)$. The correlation between chlorides and nitrogenous elements showed that they not only come from silicate minerals but also from pollution produced by human activities. Nitrogen compounds come from the degradation of organic matter by microorganisms in the surface layers of the soil, resulting in $\mathrm{CO}_{2}$ production which is then driven deep by infiltration.

Analysis of the Piper diagram showed in anions triangle, a strong grouping of points at the bicarbonated pole. This grouping is observed in the mixed triangle of cations. This behavior demonstrated that there is a dominant mineralization processes in these 
aquifers, especially the diffusion of atmospheric $\mathrm{CO}_{2}$ followed by silicate mineral weathering.

The representation of chemical analysis results in the Piper diagram allowed the identification of four families of water (Figure 6). Calcic and magnesian bicarbonated waters are the most represented in $85.1 \%$ of samples collected, and they occur throughout the study area. Besides this facies, the second facies corresponds to sodium and potassium bicarbonate water $(8.5 \%)$. There are also poorly represented facies such as chlorinated sodic-potassium $(2.1 \%)$ observed in the waters of Pangouda drill hole, the calcic and magnesian chlorinated facies encountered in drilling at Sonde and finally sulfate calciummagnesium at Tcheou.

The use of the Piper diagram for water classification has not taken into account of the acidity and mineralization of the water. To reveal these parameters, we used a hierarchical ascending classification. The dendrogram (Figure 7) from the hierarchical ascending classification showed three water classes differentiated by their electrical conductivities and their physico-chemical characteristics. Class $1(55 \%)$ concerns waters with low mineralization with an average conductivity of $240 \mu \mathrm{S} / \mathrm{cm}$. Others characteristic of this class are weak concentration in bicarbonate $\left(150 \mathrm{mg} . \mathrm{L}^{-1}\right), \mathrm{pH}$ close to neutral and weak in calcium, magnesium and sodium. Class 2 (26\% of samples) includes moderately mineralized waters. Their average conductivity is 494 $\mu \mathrm{S} / \mathrm{cm}$ and a $\mathrm{pH}$ close to neutral. These waters are rich in $\mathrm{HCO}_{3}^{-}\left(322.6 \mathrm{mg} . \mathrm{L}^{-1}\right), \mathrm{Ca}^{2+}$ (41 $\mathrm{mg} / \mathrm{L})$ and $\mathrm{Mg}^{2+}(22.7 \mathrm{mg} / \mathrm{L})$. These two classes by their low electrical conductivities showed a phenomenon of mineralization controlled by infiltration by rainwater. Class 3 concerns highly mineralized waters of the region and it represents $19 \%$ of all samples. These waters are different from the previous ones by their high conductivity $(811 \mu \mathrm{S} / \mathrm{cm})$ and their high concentration of $\mathrm{Na}^{+}, \mathrm{Cl}^{-}, \mathrm{SO}_{4}{ }^{2-}$, $\mathrm{Mg}^{2+}$ and $\mathrm{NO}_{3}{ }^{-}$. This latter class showed the impact of human activities on the water, with the presence of nitrates on the one hand, and mineralization-time residence or the phenomenon of hydrolysis of silicate minerals on the other. These waters are found in the towns of Tchitchira, Natiponi KokouTemberma, Pangouda, Sondè, Tchéou, Nandja (Broukou), Manta-Ferme, Nande .

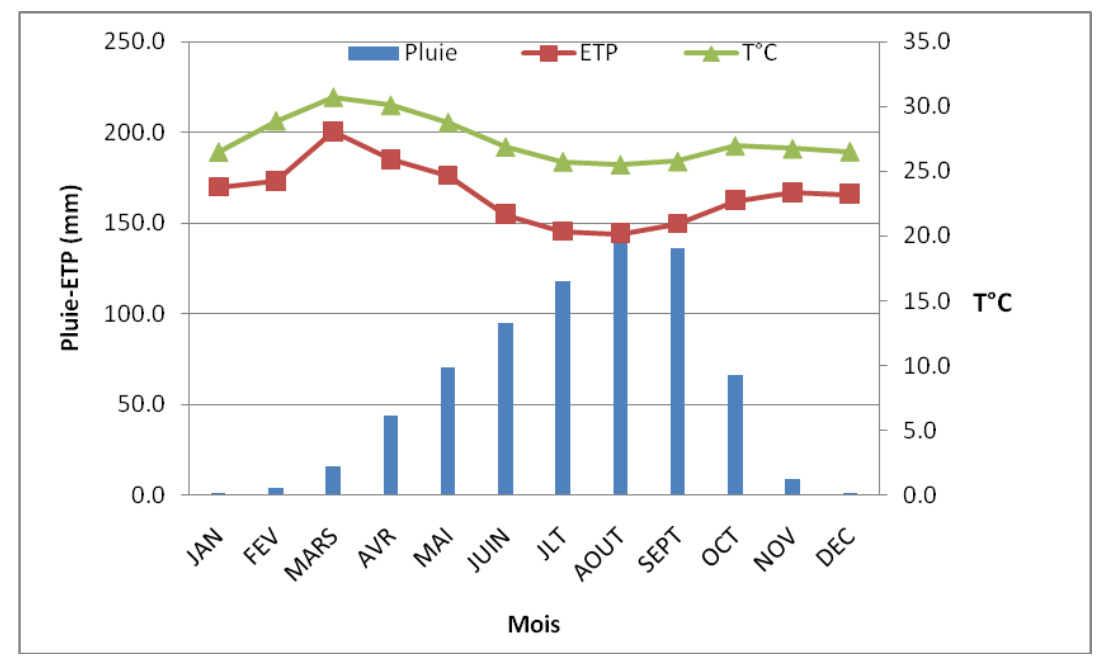

Figure 2: Monthly average values of rainfall, temperature and evapotranspiration in the Kara station (1981 - 2011). Pluie: rainfall; $\mathrm{T}^{\circ} \mathrm{C}$ : temperature; ETP: evapotranspiration; FEV: February; MARS: March; AVR: April; MAI: May; JUIN: June; JLT: July; AOUT: August. 


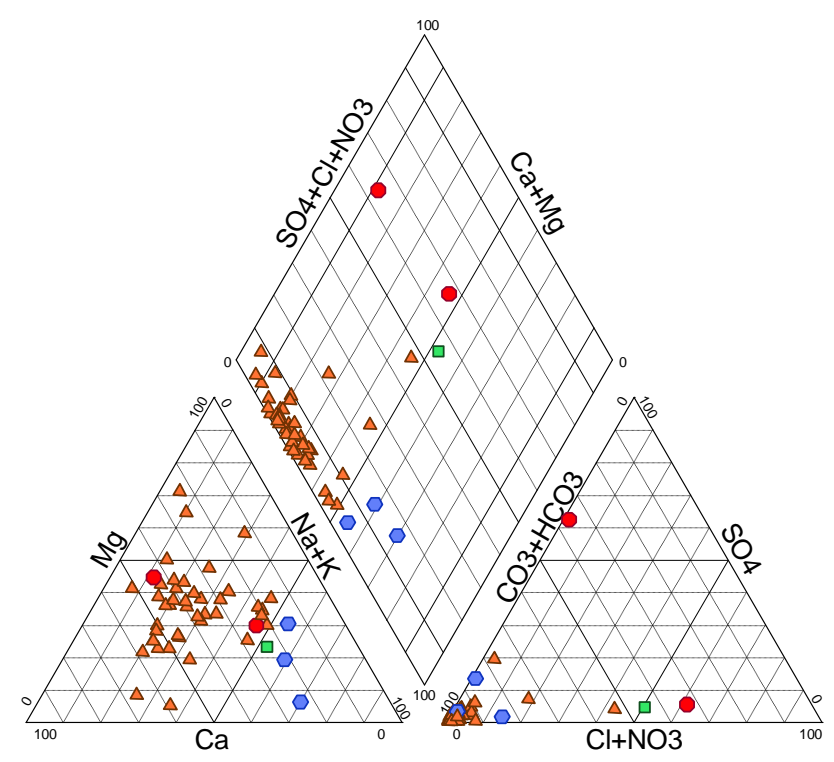

Figure 6: Hydro-chemical classification of water in Peper Diagram.

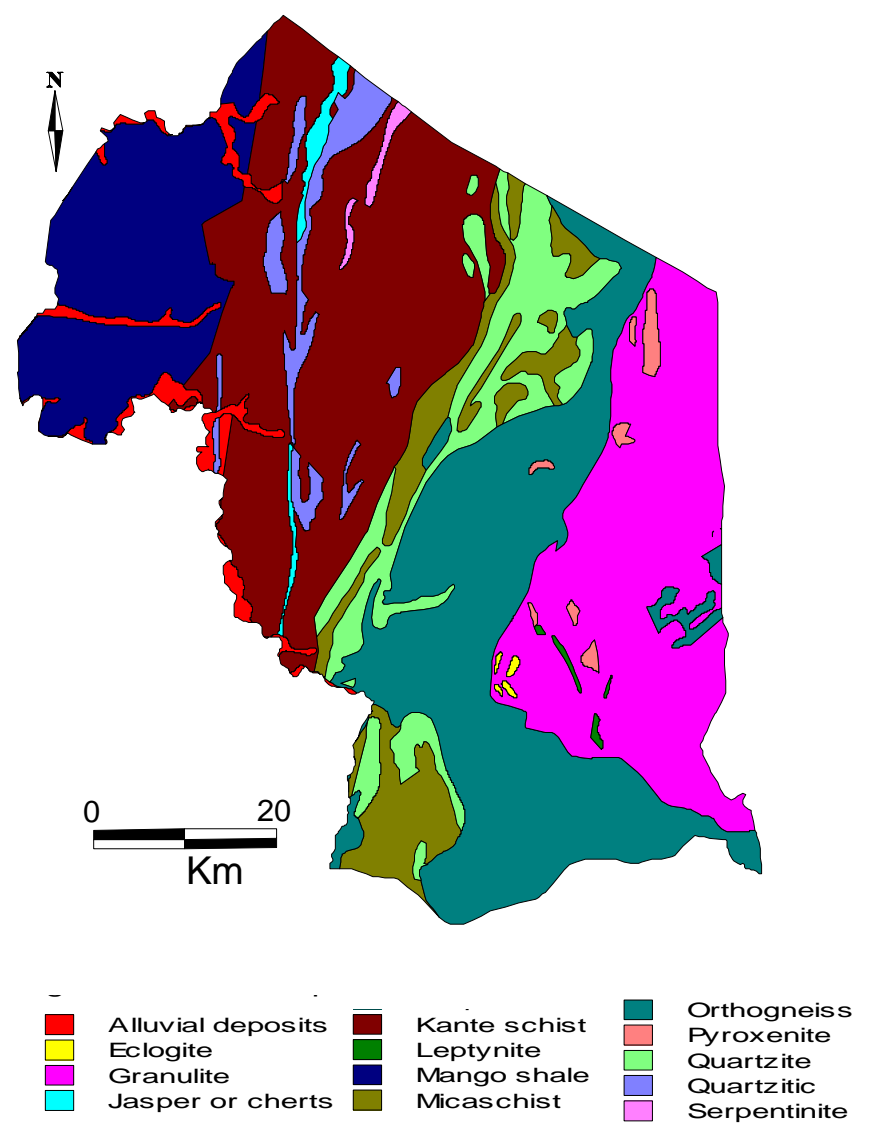

Figure 3: Geological map of the North-Est Kara Region. 


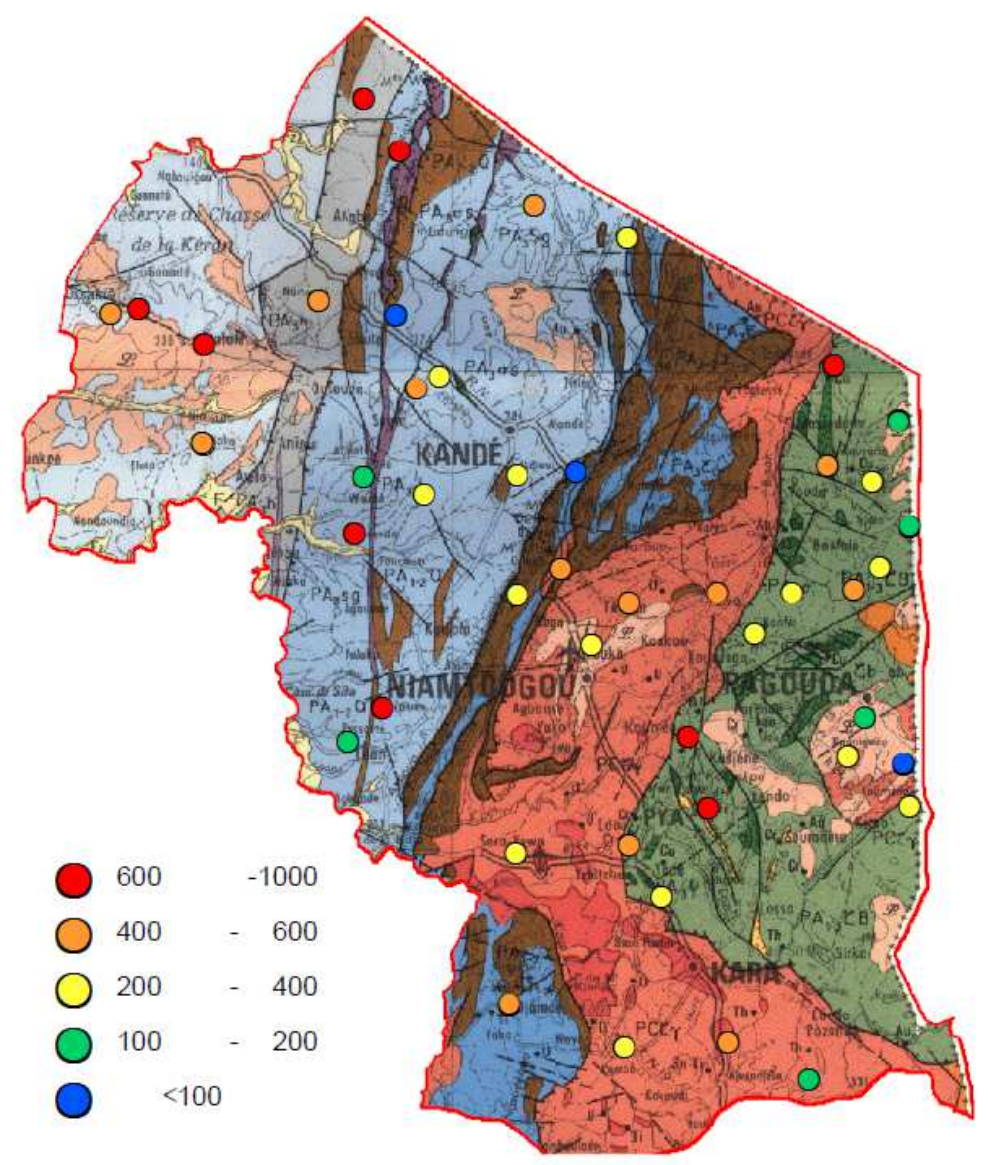

Figure 4: Distribution of conductivity on the geological background of the region.

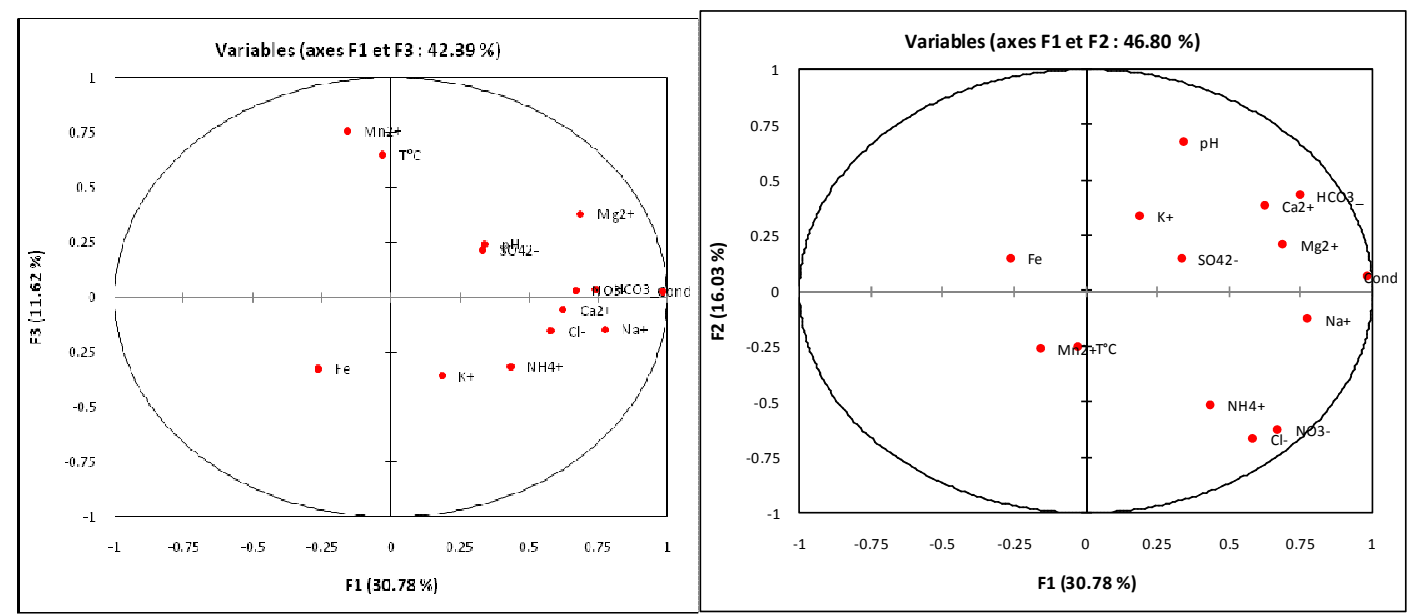

Figure 5: Correlation circles according factorial designs F1-F2 and F1-F3. 


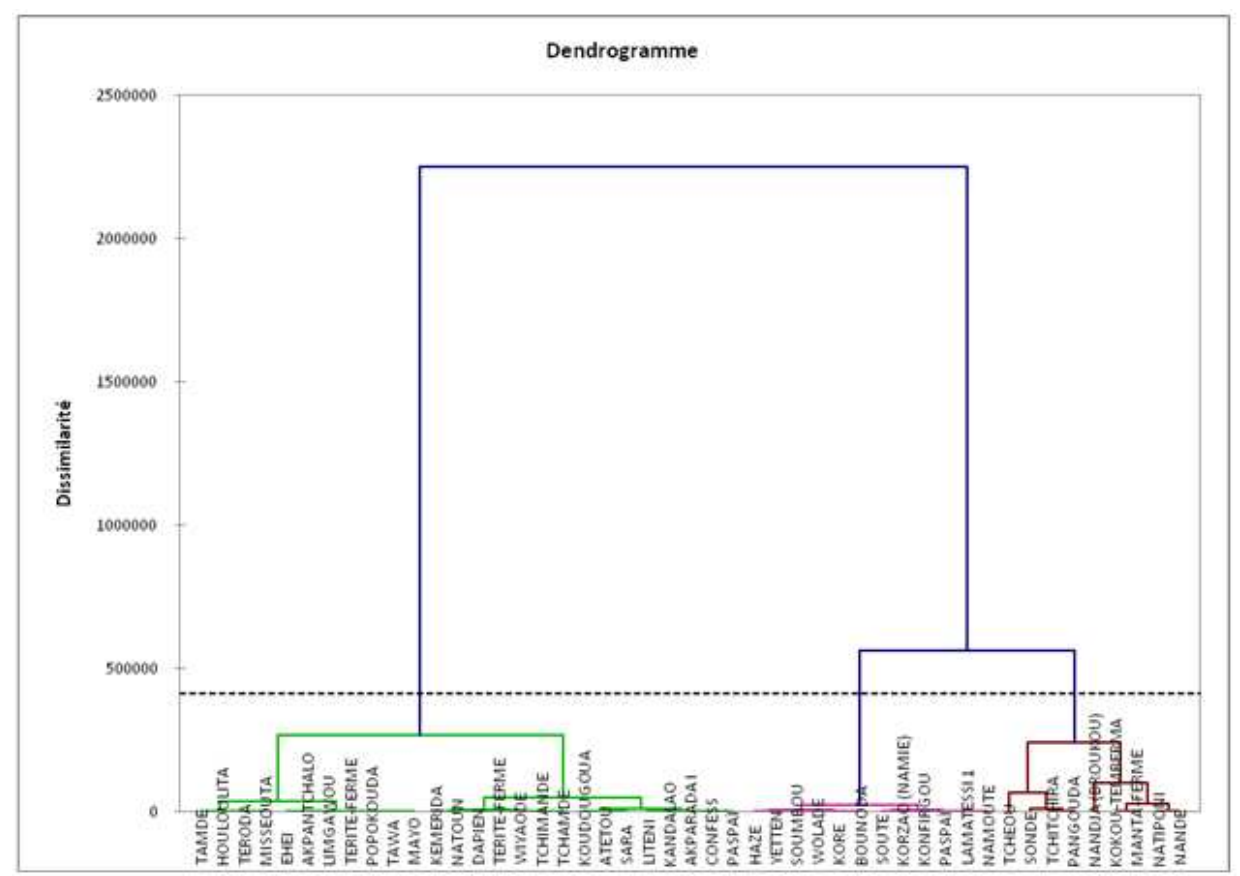

Figure 7: Dendrogram obtained from hierarchical clustering classification.

Table 1: Materials and methods used in the determination of physico-chemical parameters.

\begin{tabular}{lcccc}
\hline Parameters & Methods & $\begin{array}{c}\text { AFNOR } \\
\text { Standard }\end{array}$ & $\begin{array}{c}\text { Method } \\
\text { accuracy }\end{array}$ & Materials \\
\hline $\mathrm{pH}$ & Electrometry & NFT 90-008 & \pm 0.01 & pH- meter WTW pH 330i \\
\hline Turbidity & Nephelometry & NFT 90-33 & $\pm 0.01 \mathrm{NTU}$ & $\begin{array}{c}\text { Turbidimeter } \\
\text { DRT100B model 20012 }\end{array}$ \\
\hline Conductivity (CE) & Conductimetry & NFT 90-031 & $\pm 0.5 \%$ & $\begin{array}{c}\text { Conductimeter WTW } \\
\text { Cond 330i }\end{array}$ \\
\hline $\mathrm{Ca}^{2+}$ & $\begin{array}{c}\text { Complexometry with } \\
\text { EDTA }\end{array}$ & NFT 90-016 & $\pm 0.5 \mathrm{mg} / \mathrm{L}$ & - \\
\hline $\mathrm{Mg}^{2+}$ & $\begin{array}{c}\text { Complexometry with } \\
\text { EDTA }\end{array}$ & NFT 90-016 & $\pm 0.24 \mathrm{mg} / \mathrm{L}$ & - \\
\hline $\mathrm{Na}^{+}$ & $\begin{array}{c}\text { Atomic Absorption } \\
\text { Spectrophotometry }\end{array}$ & NFT 90-20 & $\pm 0.04 \mathrm{mg} / \mathrm{L}$ & $\begin{array}{c}\text { Spectrophotometer } \\
\text { Perkin Elmer model 2380 }\end{array}$ \\
\hline $\mathrm{K}^{+}$ & $\begin{array}{c}\text { Atomic Absorption } \\
\text { Spectrophotometry }\end{array}$ & NFT 90-20 & $\pm 0.02 \mathrm{mg} / \mathrm{L}$ & $\begin{array}{c}\text { Spectrophotometer } \\
\text { Perkin Elmer model 2380 }\end{array}$ \\
\hline $\mathrm{NH}_{4}^{+}$ & $\begin{array}{c}\text { Atomic Absorption } \\
\text { Spectrophotometry }\end{array}$ & NFT 90-015 & 1 to 2\% & $\begin{array}{c}\text { Spectrophotometer } \\
\text { Digitron Elvi 675 }\end{array}$ \\
\hline $\mathrm{Fe}_{\mathrm{T}}$ & $\begin{array}{c}\text { Molecular Absorption } \\
\text { Spectrophotometry }\end{array}$ & NFT 90-017 & 1 to 2\% & $\begin{array}{c}\text { Spectrophotometer } \\
\text { Digitron Elvi 675 }\end{array}$ \\
\hline $\mathrm{Mn}^{2+}$ & $\begin{array}{c}\text { Molecular Absorption } \\
\text { Spectrophotometry }\end{array}$ & NFT 90-024 & 1 to 2\% & $\begin{array}{c}\text { Spectrophotometer } \\
\text { Digitron Elvi 675 }\end{array}$ \\
\hline
\end{tabular}




\begin{tabular}{lcccc}
\hline $\mathrm{Cl}^{-}$ & Argentimetry & NFT 90-014 & $\pm 0.5 \mathrm{mg} / \mathrm{L}$ & - \\
\hline $\mathrm{HCO}_{3}{ }^{-}$ & Acidimetry & NFT 90-036 & $\pm 0.25 \mathrm{mg} / \mathrm{L}$ & $\begin{array}{c}\text { Spectrophotometer } \\
\text { Digitron Elvi 675 }\end{array}$ \\
\hline $\mathrm{SO}_{4}{ }^{-2}$ & Nephelometry & NFT 90-009 & 1 to 2\% & $\begin{array}{c}\text { Spectrophotometer } \\
\text { Digitron Elvi 675 }\end{array}$ \\
\hline $\mathrm{NO}_{3}^{-}$ & $\begin{array}{c}\text { Molecular Absorption } \\
\text { Spectrophotometry }\end{array}$ & NFT 90-012 & 1 to 2\% & $\begin{array}{c}\text { Spectrophotometer } \\
\text { Digitron Elvi 675 }\end{array}$ \\
\hline $\mathrm{NO}_{2}^{-}$ & $\begin{array}{c}\text { Molecular Absorption } \\
\text { Spectrophotometry }\end{array}$ & NFT 90-013 & 1 to 2\% & $\begin{array}{c}\text { Spectrophotometer } \\
\text { Digitron Elvi 675 }\end{array}$ \\
\hline
\end{tabular}

Table 2: Values of physico- chemical parameters measured $(n=60)$.

\begin{tabular}{lcccc}
\hline Parameters & Minimum & Maximum & Average & Standard Deviation \\
\hline $\mathrm{Cond}$ & 42.0 & 982.0 & 414.56 & 240.2 \\
$\mathrm{~T}^{\circ} \mathrm{C}$ & 26.1 & 32.0 & 28.7 & 1.2 \\
$\mathrm{pH}$ & 5.4 & 7.9 & 7.0 & 0.6 \\
$\mathrm{HCO}_{3}{ }^{-}$ & 18.3 & 695.4 & 239.7 & 135.5 \\
$\mathrm{Ca}^{2+}$ & 1.6 & 80.5 & 31.1 & 18.8 \\
$\mathrm{Mg}^{2+}$ & 0.7 & 51.5 & 18.2 & 12.5 \\
$\mathrm{Na}^{+}$ & 1.8 & 96.0 & 29.4 & 27.1 \\
$\mathrm{~K}^{+}$ & 0.1 & 9.7 & 2.6 & 1.9 \\
$\mathrm{NH}_{4}^{+}$ & 0.0 & 0.4 & 0.1 & 0.1 \\
$\mathrm{NO}_{3}{ }^{-}$ & 0.0 & 10.5 & 1.09 & 2.28 \\
$\mathrm{Cl}^{-}$ & 0.00 & 190.20 & 12.42 & 38.68 \\
$\mathrm{SO}_{4}{ }^{2-}$ & 0.30 & 242.30 & 10.97 & 35.24 \\
$\mathrm{FeT}^{2+}$ & 0.00 & 1.70 & 0.3573 & 0.41 \\
$\mathrm{Mn}^{2+}$ & 0.00 & 2.40 & 0.12 & 0.45 \\
\hline
\end{tabular}

\section{DISCUSSION}

The $\mathrm{pH}$ clearly acid corresponds to the waters that had a short contact time with the reservoir. This acidity is due to the presence of high quantities of free $\mathrm{CO}_{2}$ in the water. High mineralization met in the Northwest of the region where geology is characterized by sandstone and quartz sandstone of the Volta Basin can be attributed to low flow velocity of water in these formations, and therefore a long residence time of the water. The contribution of a simple dissolution in a magmatic and metamorphic region without soluble minerals such as calcite, gypsum and halite is of little significance. Moreover, the undersaturated condition of samples in calcite, gypsum and halite does not reflect the abundance soluble rocks in the region. Indeed this is confirmed by the geological (Figure 1) map which did not show soluble rock formations. The bicarbonated facies is dominant, and the production of bicarbonates is due mainly to plagioclase weathering due to the action of carbonic acid. Except potassium contents, the cation concentrations correlate well with bicarbonate ions and this correlation reflects the dissolution of silicates. 
Table 3: Correlation coefficients between physico-chemical parameters.

\begin{tabular}{|c|c|c|c|c|c|c|c|c|c|c|c|c|c|c|}
\hline Parameters & Cond & $\mathbf{T}^{\circ} \mathbf{C}$ & pH & $\mathrm{HCO}_{3^{-}}$ & $\mathrm{Ca}^{2+}$ & $\mathrm{Mg}^{2+}$ & $\mathrm{Na}^{+}$ & $\mathbf{K}^{+}$ & $\mathbf{N H}_{4}{ }^{+}$ & $\mathrm{NO}_{3}^{-}$ & $\mathrm{Cl}^{-}$ & $\mathrm{SO}_{4}{ }^{2-}$ & $\mathbf{F e}$ & $\mathrm{Mn}^{2+}$ \\
\hline Cond & 1 & & & & & & & & & & & & & \\
\hline $\mathrm{T}^{\circ} \mathrm{C}$ & -0.014 & 1 & & & & & & & & & & & & \\
\hline $\mathrm{pH}$ & 0.34 & -0.02 & 1 & & & & & & & & & & & \\
\hline $\mathrm{HCO}_{3}^{-}$ & 0.78 & -0.07 & 0.47 & 1 & & & & & & & & & & \\
\hline $\mathrm{Ca}^{2+}$ & 0.73 & -0.09 & 0.44 & 0.07 & 1 & & & & & & & & & \\
\hline $\mathrm{Mg}^{2+}$ & 0.78 & 0.01 & 0.41 & 0.73 & 0.48 & 1 & & & & & & & & \\
\hline $\mathrm{Na}^{+}$ & 0.84 & -0.01 & 0.07 & 0.61 & 0.41 & 0.48 & 1 & & & & & & & \\
\hline $\mathrm{K}^{+}$ & 0.19 & -0.03 & 0.18 & 0.21 & 0.25 & -0.07 & 0.24 & 1 & & & & & & \\
\hline $\mathrm{NH}_{4}^{+}$ & 0.33 & -0.06 & -0.27 & 0.08 & 0.24 & 0.12 & 0.39 & 0.06 & 1 & & & & & \\
\hline $\mathrm{NO}_{3}^{-}$ & 0.61 & 0.14 & -0.08 & 0.22 & 0.25 & 0.41 & 0.61 & -0.10 & 0.43 & 1 & & & & \\
\hline $\mathrm{Cl}^{-}$ & 0.52 & 0.06 & -0.17 & -0.01 & 0.19 & 0.21 & 0.62 & -0.01 & 0.58 & 0.81 & 1 & & & \\
\hline $\mathrm{SO}_{4}{ }^{2-}$ & 0.36 & -0.01 & 0.13 & 0.01 & 0.35 & 0.33 & 0.1 & 0.02 & 0.01 & 0.12 & 0.08 & 1 & & \\
\hline $\mathrm{Fe}$ & -0.21 & -0.05 & -0.04 & -0.08 & -0.09 & -0.22 & -0.15 & 0.12 & -0.14 & -0.19 & -0.17 & -0.17 & 1 & \\
\hline $\mathrm{Mn}^{2+}$ & -0.15 & 0.48 & -0.06 & -0.13 & -0.19 & 0.05 & -0.20 & -0.2 & -0.08 & 0.07 & -0.05 & -0.04 & -0.08 & 1 \\
\hline
\end{tabular}

Tableau 4: Characteristics of different water classes.

\begin{tabular}{|c|c|c|c|c|c|c|c|c|c|c|c|c|c|c|}
\hline Classes & $\begin{array}{c}\text { Cond } \\
\mu \mathrm{S} / \mathrm{cm}\end{array}$ & $\mathbf{T}^{\circ} \mathbf{C}$ & pH & $\begin{array}{l}\mathrm{HCO}_{3}^{-} \\
\text {mg.L }^{-1}\end{array}$ & $\begin{array}{c}\mathrm{Ca}^{2+} \\
\mathrm{mg.L}^{-1}\end{array}$ & $\begin{array}{l}\mathrm{Mg}^{2+} \\
\text { mg.L }\end{array}$ & $\begin{array}{c}\mathrm{Na}^{+} \\
\mathrm{mg.L}^{-1}\end{array}$ & $\begin{array}{c}\mathrm{K}^{+} \\
\mathrm{mg} \cdot \mathrm{L}^{-1}\end{array}$ & $\begin{array}{l}\mathrm{NH}_{4}+ \\
\text { mg. }^{-1}\end{array}$ & $\begin{array}{l}\mathrm{NO}_{3}^{-} \\
\text {mg.L }^{-1}\end{array}$ & $\begin{array}{c}\mathrm{Cl}^{-} \\
\mathrm{mg} \cdot \mathrm{L}^{-1}\end{array}$ & $\begin{array}{c}\mathrm{SO}_{4}{ }^{2-} \\
\text { mg.. }{ }^{-1}\end{array}$ & $\begin{array}{c}\text { Fe } \\
\text { mg.L } L^{-1}\end{array}$ & $\begin{array}{l}\mathrm{Mn}^{2+} \\
\text { mg.L }{ }^{-1}\end{array}$ \\
\hline 1 & 240.2 & 28.6 & 6.9 & 152.3 & 20.4 & 10.8 & 13.2 & 2.3 & 0.0 & 0.3 & 2.0 & 2.8 & 0.4 & 0.1 \\
\hline 2 & 494.6 & 28.9 & 7.3 & 322.6 & 41.6 & 22.7 & 32.8 & 2.8 & 0.0 & 0.5 & 3.6 & 7.1 & 0.4 & 0.2 \\
\hline 3 & 811.6 & 28.8 & 7.1 & 381.7 & 47.9 & 33.7 & 71.7 & 3.2 & 0.1 & 4.0 & 54 & 39.8 & 0.2 & 0.0 \\
\hline
\end{tabular}


Principal component analysis and hierarchical ascending classification gave the same results for the origin of groundwater mineralization in the region. These studies showed that groundwater mineralization is controlled by the nature of the geological formations. Indeed, the origin of ions in groundwater is controlled by the water-rock contact as indicated by the results of different statistical studies. The geology of the region is dominated by Proterozoic formations consisting mainly of gneiss and schist. Hydrolysis of these rocks rich in alkali feldspar and plagioclase, explains why the contents of $\mathrm{Ca}^{2+}$ and $\mathrm{Na}^{+}$are dominant for the cations. These ions are derived from the weathering of rocks and the hydrolysis of silicate minerals (Savané et al., 2001). The sizeable proportion of anorthite in plagioclase, a variety most easily weatherable (Faillat and Drugs, 1993) explains the concentration of $\mathrm{Ca}^{2+}\left(72\right.$ meq. $\left.{ }^{-1}\right)$ greater than that of $\mathrm{Na}^{+}(60$ meq. $\left.\mathrm{L}^{-1}\right)$ in the waters. Indeed, the calcium is included in the structure of plagioclase. According to Soro (2002), the calcium released during acid hydrolysis of plagioclase, moves together with the bicarbonates in the water according to reaction 1 :

$5\left(\mathrm{Na}_{0.8}, \mathrm{Ca}_{0.2}\right)\left(\mathrm{Al}_{1.2} \mathrm{Si}_{2.8}, \mathrm{O}_{8}\right)+6 \mathrm{H}^{+}+19 \mathrm{H}_{2} \mathrm{O}$ $\rightarrow 3 \mathrm{Al}_{2} \mathrm{O}_{5}(\mathrm{OH})_{4}+4 \mathrm{Na}^{+}+\mathrm{Ca}^{2+}+8 \mathrm{H}_{4} \mathrm{SiO}_{4}$ (1)

This reaction is more pronounced in groundwater and so the correlation between $\mathrm{Ca}^{2+}$ and $\mathrm{HCO}_{3}{ }^{-}$is high $(\mathrm{r}=0.5)$. The correlation coefficient of 0.5 demonstrates that all the calcium released does not go into the water, but can also join ion exchange reactions with sodium. The mineralization of the calcium of basement water is under the influence of the weathering and hydrolysis of aluminosilicate minerals rich in $\mathrm{Ca}^{2+}$ like anorthite (reaction 2):

$\mathrm{CaAl}_{2} \mathrm{Si}_{2} \mathrm{O}_{8}+2 \mathrm{CO}_{2}+3 \mathrm{H}_{2} \mathrm{O} \rightarrow \mathrm{Ca}^{2+}+$ $2 \mathrm{HCO}_{3}{ }^{-}+\mathrm{Al}_{2} \mathrm{Si}_{2} \mathrm{O}_{5}(\mathrm{OH})_{4}$

Sodium comes from albite weathering according to the reaction (3)

$2 \mathrm{NaAlSi}_{3} \mathrm{O}_{8}+\mathrm{H}_{2} \mathrm{O}+\mathrm{CO}_{2} \rightarrow$ $11 \mathrm{Al}_{2} \mathrm{Si}_{2} \mathrm{O}_{5}(\mathrm{OH})_{4}+2 \mathrm{Na}^{+}+2 \mathrm{HCO}_{3}^{-}+4 \mathrm{H}_{4} \mathrm{SiO}_{4}$ (4)

The $\mathrm{Mg}^{2+} / \mathrm{Ca}^{2+}$ ratio for $53 \%$ of the sampled is below 1 , indicating that $\mathrm{Mg}^{2+}$ ions are produced by the decomposition of ferromagnesian minerals such as biotite and amphibole present in the rocks. The $\mathrm{Na}^{+} / \mathrm{K}^{+}$ ratio highly variable and greater than 1 for all samples confirms the predominance of sodium ions over potassium. It varies from 1.7 to 57.24 for almost all samples. Nevertheless, extremely high values of this ratio are reported in water at Kandalao (117.3), Tchimandé (166.7), and Sonde (255.7). In any case, this showed a predominance of sodium ion over potassium in the water. The predominance of $\mathrm{Na}^{+}$over $\mathrm{K}^{+}$ions can be explained firstly by the high stability of muscovite and feldspar and secondly by the selective adsorption of potassium ions by clays (Banton and Bangoy, 1997). According to Tardy (1969) a weak $\mathrm{Na}^{+} / \mathrm{K}^{+}$ratio reflects an environment well drained subjected to a rapid potassic feldspar deterioration. The presence of $\mathrm{CO}_{2}$ in the water from soil facilitates the hydrolysis of the silicates which allows the production of $\mathrm{HCO}_{3}^{-}$(Faillat and Drugs, 1993). This phenomenon explains why the water from fissured layer presents higher levels of the $\mathrm{HCO}_{3}^{-}\left(274.5 \mathrm{mg} . \mathrm{L}^{-1}\right)$ and the highest $\mathrm{pH}$ (around 7). The dissolution of this ion in water is controlled by the partial pressure of biogenic $\mathrm{CO}_{2}$ (Soro, 2002), the study area is an agricultural region. It is during rainwater infiltration into the reservoirs that, water charged with $\mathrm{CO}_{2}$ dissolves rocks and becomes rich in bicarbonate. It is this acid hydrolysis of surrounding rocks that controls the bicarbonated facies diversity of groundwater. $\mathrm{Cl}^{-}, \mathrm{SO}_{4}{ }^{2-}$ and $\mathrm{NO}_{3}{ }^{-}$ions and some cations are derived from rain and soil leaching by rainwater as indicated by multivariate analysis results. Thus, Akiti (1980) showed that chloride content in meteoric waters is low in the region and almost never exceeds $30 \mathrm{mg} \cdot \mathrm{L}^{-1}$. Evaporation phenomena affecting infiltration water in this case could increase chloride concentrations in groundwater (Edmunds and Gaye, 1996). This hypothesis is verified if we consider the drill holes at Pangouda and Sonde with the highest levels of $\mathrm{Cl}^{-}$and they are located in depressions. This showed that rainwater is the main source of production of $\mathrm{Cl}^{-}$ions in groundwater. Nitrates $\left(\mathrm{NO}_{3}{ }^{-}\right)$are observed significantly in drillings which correspond to high levels of chloride. As well as chlorides in 
the groundwater of the region, nitrates probably come from surface contributions and would be related to human activities. Also, Atteia. (2005) showed that the $\mathrm{NO}_{3}{ }^{-}$ions are usually derived from pollution due to human activities. The influence of anthropogenic activities in the mineralization of groundwater has also been highlighted in groundwater in Senegal (Tandia, 2000; Cissé, 2000). The other nitrogen elements such as nitrites and ammonium were below their detection threshold levels which are 0.025 and 0.05 $\mathrm{mg} . \mathrm{L}^{-1}$ respectively. The absence of these two elements in water, characteristic of anaerobic environments and thus confined (Atteia, 2005), showed that the basement aquifers of the region are an open system, favoring exchanges with the atmosphere. However it should be noted that with a maximum content of $10.5 \mathrm{mg} . \mathrm{L}$ less than $50 \mathrm{mg} . \mathrm{L}^{-1}$ corresponding to the standard set by the WHO (WHO, 2011; Rodier 2011), nitrates in this case do not present a health problem. Low contents of sulphate in underground waters in the area are a feature of the groundwater of basement zones (Mbonu, 1991). Indeed, for Travi and Mudry (1997), the levels of chlorides and sulfates are usually low in crystalline basement reservoirs of West Africa. According to these authors, rainwater represents the source of production of $\mathrm{SO}_{4}{ }^{2-}$ ions in groundwater.

\section{Conclusion}

The study of the origin of the mineralization of the water of discontinuous aquifers in the northeastern part of the Kara region from a combination of graphics and hydro-chemical methods and statistical analysis led to the identification of different characteristics of groundwater in the region. Groundwater has a temperature between 25.6 ${ }^{\circ} \mathrm{C}$ and $29.2^{\circ} \mathrm{C}$, with an average of $27.7^{\circ} \mathrm{C}$. These waters have $\mathrm{pH}$ close to neutral, with a hardness ranging between $1{ }^{\circ} \mathrm{F}$ and $30{ }^{\circ} \mathrm{F}$. Groundwater of the target region consists mainly of two big families which are calcic and magnesian bicarbonated families on the one hand, sodic and potassic bicarbonated on the other hand. Occasionally, the sodic and potassic chlorinated, and calcic and magnesian sulphated families were identified.
Hierarchical ascending classification was used to determine three classes taking into account water conductivity, $\mathrm{pH}$ and ions contents. Principal component analysis showed that the mineralization of groundwater is controlled by the nature of the geological formations in the region. And major ions are derived from the weathering of rocks, the acid hydrolysis of silicate minerals such as anorthite and albite in plagioclase, the decomposition of ferromagnesian minerals such as biotite and amphibole present in the rocks. The amount of the soluble components present in the water is closely related to the intensity of weathering and the degree of soil leaching. The presence of $\mathrm{Cl}^{-}$and $\mathrm{SO}_{4}{ }^{2-}$ in groundwater is related to rainwater and soil leaching. Inorganic nitrogen especially nitrates were derived from human pollution.

\section{REFERENCES}

Addra TC, Fahem AK, De Jong T, Mank T. 1984. Atlas du développement Régional du Togo, Direction de la Cartographie Nationale et du Cadastre. P.N.U.D. D.T.C.D., p.38.

AFNOR. 1996. Eaux, méthodes d'essai. Ed. Afnor. 624p.

Akiti TT. 1980. Etude géochimique et isotopique de quelques aquifères du Ghana: Gneiss de la plaine d'Accra, calcaires de la plaine au sud-est de la Volta, granite de la haute région. Thèse Doct. d'ingénieur, Univ de Paris Sud (ORSAY), 232p.

Atteia O. 2005 : Chimie et Pollution des Eaux Souterraines. Editions TEC \& Doc: Lavoisier ; 398.

Blavoux B, Mudry J, Puig J. 1992. Bilan, fonctionnement et protection du système karstique de la Fontaine du Vaucluse (SE de la France). International Contribution to Hydrogeology, 13: 116-131.

Assouma D. 1988. Etude par modèle mathématique de la structure et du fonctionnement d'un aquifère de socle exploité en région tropicale. (Alimentation en eau potable de la ville de Dapaong -TOGO). Thèse de $3^{\mathrm{e}}$ cycle, Univ. d'Orléans, 21.

Banton O, Bangoy LM. 1997. Hydrogéologie, Multiscience Environnementale des Eaux 
Souterraines. Presse de l'Univ. du Québec/AUPEL : Québec ; 460.

Cissé S. 2000. Nappe libre des sables quaternaires Thiaroye/Beer Thialane. Etude de la contamination par les nitrates sur la basse d'un système d'informations géographiques (PC/ARC/INFO). Thèse 3e cycle, Univ. CAD, Dakar, 193.

DGEA. 2009. Rapport de synthèse Gestion Intégrée des Ressources en Eau (GIRE) et objectifs du millénaire pour le développement (OMD). UNDESA, p39.

DGSCN. 2011. Recensement général de la population et de l'habitat: Résultats définitifs, DGSCN, 57p.

Faillat JP, Drogue C. 1993. Différenciation hydrochimique de nappes superposées d'altérites et de fissures en socle granitique. Hydrogical Sciences-Journal des Sciences Hydrologiques, 3(6): 215229.

Fahmy T. 2011. www.xlstat.com. Addinsoft (1995-2012).

Gaye CB, Edmunds WM. 1996. Groundwater recharge estimation using chloride, stable isotopes and tritium profiles in the sands of northwestern Senegal. Environnemental Geology 27: 246-251.

Gilli E, Mangan C, Mudry J. 2004. Hydrogéologie : Objets, Méthodes, Applications. Dunod : Paris ; 299.

Lefebvre JC. 1980. Introduction aux Analyses Statistiques Multidimensionnelles $\quad\left(2^{\mathrm{e}}\right.$ edn). Masson : Paris ; 259.

Mbonu M. 1991: Hydrogéologie, hydrochimie et géochimie isotopique des aquifères de socle du plateau de Jos et des plaine environnantes (Nigéria). Thèse Université d'Avignon et des Pays de Vaucluse, France, 80.

PNUD. 1982. Stratégie d'aménagement des eaux, ressources et besoins en eau. Laboratoire Centrale d'Hydraulique de France. 11 notices et 11planches, PNUD.

Rodier J, Legube B, Merlet N et al. 2009. L'Analyse de l'Eau: Eaux Naturelles, Eaux Résiduaires, Eaux de Mer ( $9^{\mathrm{e}}$ édn). Dunod : Paris ; 1526 p.

Simler R. 2005. Logiciel d'hydrochimie/ Diagrammes. http//www.lha.univavignon.fr/logiciel.htm.
Soro N. 2002. Hydrochimie et géochimie isotopique des eaux souterraines du degré carré de Grand-Lahou et ses environs (sud-ouest de la Côte d'Ivoire). Implication hydrologique et hydrogéologique. Thèse d'Etat, Université de Cocody, p. 272.

Sylvain JP, Aregba A, Assih-Edeou P, Casting C, Chevremont J, Collart J, Monciardini C, Marteau P, Ouasane I, Tchota K. 1986. Notice explicative de la carte géologique à $1 / 200000$. Feuille de Kara. Mémoire ${ }^{\circ}$ 5 DGMG/BNRM ( $1^{\mathrm{e}}$ édn), 64p +2 annexes.

Taïrou MS. 2006. La tectonique tangentielle panafricaine au Nord-Togo. Thèse de Doct., Univ. Lomé, 401p.

Tandia AA. 2000. Origine, évolution et migration des formes de l'azote minéral dans les aquifères situés sous environnement périurbain non assaini : cas de la nappe des sables quaternaires de la région de Dakar. Thèse ès sci., Univ. CAD, Dakar, 210 p.

Tardy Y. 1969. Géochimie des altérations. Etude des arènes et des eaux de quelques massifs cristallins d'Europe et d'Afrique. Thèse Doct. ès Sci, Univ. Louis Pasteur, Strasbourg, p199.

TDE-SDP. 2010. Tableau de production d'eau brute des centres et secteurs. Rapport de production.

Yidana SM, Ophori D, Banoeng-Yakubo B. 2008. A multivariate statistical analysis of surface water chemistry data. The Ankobra Basin, Ghana. Journal of Environmental Management, 86: 80-87.

Yidana SM. 2010. Groundwater classification using multivariate statistical methods: Southern Ghana. Journal of African Earth Sciences, 57: 455-469.

WHO. 2011. Guidelines for Drinking Water Quality $\left(4^{\text {th }}\right.$ edn). World Health Organisation: Geneva. 